\title{
Estimation of crop evapotranspiration and crop coefficients of rice (Oryza sativa L.) under low land condition
}

\author{
KISHOR MOTE ${ }^{1}$, V.PRAVEEN RAO ${ }^{2}$, K.AVIL KUMAR ${ }^{2}$ and V. RAMULU ${ }^{2}$ \\ Agronomy Division, Central Coffee Research Institute, Chikmagaluru -577117, Karnataka. ${ }^{2}$ Department of Agronomy, \\ Professor Jayashankar Telangana State Agriculture University, Hyderabad-500 030. \\ *Corresponding author E-mail: kishormote56@gmail.com
}

\begin{abstract}
An attempt has been made to estimate the crop evapotranspiration (ETc) and Kc under alternate wetting and drying method (AWD) of water management of rice (Oryza sativa L.) under lowland condition during 2013 and 2014 at Rajendranagar, Hyderabad. The average seasonal ETc was highest in continuous submergence (Cs) of $3-\mathrm{cm}$ depth from transplanting to panicle initiation (PI) and $5-\mathrm{cm}$ from $\mathrm{PI}$ to physiological maturity (PM) $(657.8 \mathrm{~mm})$ followed by AWD irrigation regimes of flooding to a water depth of $5-\mathrm{cm}$ between 15 DAT to PM and when ponded water level drops to 5-cm below ground level in field water tube $(628 \mathrm{~mm})$. The results suggested that the roots of rice were able to extract adequate amount of water to satisfy its ETc needs for 2-7 days in different treatments of AWD. The mean crop coefficient values worked out were $1.35,1.59,1.81$ and 1.33 at initial establishment stage, vegetative and panicle initiation stage, at panicle development stage and at ripening and maturity stage.
\end{abstract}

Keywords: Alternate wetting and drying, continuous flooding, crop coefficient, evapotranspiration, Field water tube, lowland rice.

Rice (Oryza sativa L.) is one of the world's major food crops and as well as for India. The area under rice in India is 45 million ha with production of 106.19 million tonnes. Telangana State is a key rice production region with 25.57 lakh ha under irrigation (Department of Agriculture, Telangana, 2014). The conventional water management in lowland rice consume about 70 to 80 per cent of the total irrigated fresh water resources in the major part of the rice growing regions in Asia including India (Bouman et al., 2007). Rapid population growth, urbanization and multiple competing demands for water (i.e., drinking, industrial uses) have contributed to irrigation water scarcity (Tabbal et al., 2002). The occurrence of water scarcity prompted researchers to find ways to optimize water use under water saving systems in irrigated rice fields in the tropics where high yield is critical to ensure food security (Rosegrant and Ringler, 1998).

Several water saving practices and production systems have been identified already. Among them, alternate wetting and drying (AWD) irrigation performed well under low land rice cultivation without reduction in yield (Tuong, 2007). To determine the timing of AWD irrigation practice, the water level in the soil is monitored by a field water tube. Field water tube is practical device to monitor the depth of ponded water in the field for implementing AWD irrigation practice.
After irrigation, the depth of ponded water will gradually decrease and the drop in the water depth is monitored by this tube. The tube is made of $40 \mathrm{~cm}$ long PVC pipe with a diameter of $15 \mathrm{~cm}$, perforating on all sides. The tube is placed vertically to $20 \mathrm{~cm}$ depth inside the soil in a flat area of the field close to a bund for easy monitoring of water level drop in the tube. The practice of "safe" AWD now promoted as a mature water-saving technology entails irrigation when water level fall in to a threshold depth below the soil surface (Bouman et al., 2007).

Because of over flooding of water in the field much of the water are lost in the form of evapotranspiration, that's why it is necessary to evaluate evapotranspiration (Bhavsar and Patel, 2016). In light of the concerns about irrigation water scarcity due to recurrent droughts in Telangana, the present experiment was designed to estimate the crop evapotranspiration and crop coefficients of rice (Oryza sativa $L$.) under low land condition.

\section{MATERIALS AND METHODS}

The field experiment was conducted during kharif 2013 and 2014 in a sandy clay soil at Water Technology Centre, College Farm, College of Agriculture, Rajendranagar (17032' N, 78040' E. 542.6 m a.s.1.), Hyderabad. Agroclimatologically the area is classified as Southern Telangana 
Table 1: Treatment details, applied water, effective rainfall and total water input $(\mathrm{mm})$ as influenced by different AWD irrigation regimes on pooled basis (2013 and 2014) .

\begin{tabular}{|c|c|c|c|c|c|}
\hline $\begin{array}{l}\text { Treatment } \\
\text { code }\end{array}$ & Treatment details & $\begin{array}{l}\text { Applied } \\
\text { water }(\mathrm{mm})\end{array}$ & $\begin{array}{l}\text { Effective } \\
\text { rainfall }(\mathrm{mm})\end{array}$ & $\begin{array}{l}\text { Total } \\
\text { water input * } \\
(\mathrm{mm})\end{array}$ & $\begin{array}{l}\text { Water } \\
\text { saving } \\
(\%)\end{array}$ \\
\hline $\mathrm{I}_{1}$ & $\begin{array}{l}\text { Continuous submergence of } 3 \mathrm{~cm} \\
\text { up to PI and thereafter } 5 \mathrm{~cm} \text { up to } \mathrm{PM}\end{array}$ & 1390 & 216 & 1646 & - \\
\hline $\mathrm{I}_{2}$ & $\begin{array}{l}\text { AWD - Flooding to a water depth of } 3 \mathrm{~cm} \\
\text { when water level drops to } 5 \mathrm{~cm} \mathrm{BGL} \mathrm{from} \\
15 \text { DAT to PM }\end{array}$ & 1142 & 238 & 1420 & 13.7 \\
\hline $\mathrm{I}_{3}$ & $\begin{array}{l}\text { AWD - Flooding to a water depth of } 3 \mathrm{~cm} \\
\text { when water level drops to } 10 \mathrm{~cm} \mathrm{BGL} \mathrm{from} \\
15 \text { DAT to PM }\end{array}$ & 885 & 251 & 1176 & 28.6 \\
\hline $\mathrm{I}_{4}$ & $\begin{array}{l}\text { AWD - Flooding to a water depth of } 3 \mathrm{~cm} \\
\text { when water level drops to } 15 \mathrm{~cm} \mathrm{BGL} \mathrm{from} \\
15 \text { DAT to PM }\end{array}$ & 823 & 264 & 1127 & 31.5 \\
\hline $\mathrm{I}_{5}$ & $\begin{array}{l}\text { AWD - Flooding to a water depth of } 5 \mathrm{~cm} \\
\text { when water level drops to } 5 \mathrm{~cm} \text { BGL from } \\
15 \text { DAT to PM }\end{array}$ & 922 & 246 & 1208 & 26.6 \\
\hline $\mathrm{I}_{6}$ & $\begin{array}{l}\text { AWD - Flooding to a water depth of } 5 \mathrm{~cm} \\
\text { when water level drops to } 10 \mathrm{~cm} \mathrm{BGL} \mathrm{from} \\
15 \text { DAT to PM }\end{array}$ & 752 & 276 & 1069 & 35.0 \\
\hline $\mathrm{I}_{7}$ & $\begin{array}{l}\text { AWD - Flooding to a water depth of } 5 \mathrm{~cm} \\
\text { when water level drops to } 15 \mathrm{~cm} \mathrm{BGL} \mathrm{from} \\
15 \text { DAT to PM }\end{array}$ & 708 & 300 & 1048 & 36.4 \\
\hline $\mathrm{I}_{8}$ & $\begin{array}{l}\text { AWD - Flooding to a water depth of } 3 \mathrm{~cm} \\
\text { from } 15 \text { DAT to PI and thereafter } 5 \mathrm{~cm} \text { up to } \\
\text { PM when water level drops to } 15 \mathrm{~cm}\end{array}$ & 734 & 274 & 1048 & 36.3 \\
\hline
\end{tabular}

(* $40 \mathrm{~mm}$ for nursery raising)

PI - Panicle initiation; PM - Physiological maturity; DAT - Days after transplanting; BGL - Below ground level AWD - Alternate wetting and drying

Agro Climatic Zone of Telangana State. The experimental soil was sandy clay in texture, moderately alkaline in reaction, non-saline, low in organic carbon content, low in available nitrogen $(\mathrm{N})$, medium in available phosphorous $\left(\mathrm{P}_{2} \mathrm{O}_{5}\right)$ and potassium $\left(\mathrm{K}_{2} \mathrm{O}\right)$. The treatments consisted of continuous submergence (CS) throughout the crop growing season besides alternate wetting and drying (AWD) irrigation regimes with two ponded water depths of 3 and $5 \mathrm{~cm}$ and drop in ponded water levels in field water tube below ground level to 5,10 and $15 \mathrm{~cm}$ depth. The eight treatments were laid out in randomized block design with three replications (Table 1). It may be seen that under different AWD treatments there were 13.7 to 36.4 per cent saving in water in comparison to continuous submergence treatment. The recommended dose of 120:60:60 N, $\mathrm{P}_{2} \mathrm{O}_{5}$ and $\mathrm{K}_{2} \mathrm{O} \mathrm{kg} \mathrm{ha}^{-1}$ was applied. Total nitrogen was applied in the form of urea in three equal splits viz., $1 / 3 \mathrm{rd}$ as basal, $1 / 3 \mathrm{rd}$ at active tillering stage and $1 / 3 \mathrm{rd}$ at PI stage. The entire $\mathrm{P}$ was applied as basal in the form of single super phosphate $\left(16 \% \mathrm{P}_{2} \mathrm{O}_{5}\right)$. Whereas, the $\mathrm{K}$ was applied in the form of muriate of potash $\left(60 \% \mathrm{~K}_{2} \mathrm{O}\right)$ in two equal splits viz., as basal and top dressing at panicle initiation stage.

Rice variety MTU - 1010 with duration of $120-125$ days adopting a spacing of $15 \times 15 \mathrm{~cm}$ was used as a test variety in the present field experiment during both the years. The varietal characteristics of the cultivar used in the experiment are Parentage- Krishnaveni x IR-64, Habit-Semi dwarf erect, Panicle - Compact, dense, Grain type- Long 
Table 2: Crop evapotranspiration (ETc) (mm) and crop coefficient (Kc) of rice as influenced by irrigation re gimes (continuous submergence and AWD irrigation regimes) at different crop growth stages on pooled basis

\begin{tabular}{|c|c|c|c|c|c|c|c|c|c|}
\hline \multirow[t]{2}{*}{$\begin{array}{l}\text { Treatment } \\
\text { code }\end{array}$} & \multicolumn{2}{|c|}{$\begin{array}{l}\text { Initial stage } \\
(0-15 \mathrm{DAT})\end{array}$} & \multicolumn{2}{|c|}{$\begin{array}{c}\text { Development stage } \\
\quad(16-45 \mathrm{DAT})\end{array}$} & \multicolumn{2}{|c|}{$\begin{array}{l}\text { Reproductive stage } \\
\quad(46-75 \mathrm{DAT})\end{array}$} & \multicolumn{2}{|c|}{$\begin{array}{c}\text { Late stage } \\
(76-100 \mathrm{DAT})\end{array}$} & \multirow[t]{2}{*}{$\begin{array}{c}\text { Total } \\
\text { ETc }(\mathrm{mm})\end{array}$} \\
\hline & $\operatorname{ETc}(\mathrm{mm})$ & $\mathrm{Kc}$ & $\operatorname{ETc}(\mathrm{mm})$ & $\mathrm{Kc}$ & $\operatorname{ETc}(\mathrm{mm})$ & $\mathrm{Kc}$ & $\mathrm{ETc}(\mathrm{mm})$ & $\mathrm{Kc}$ & \\
\hline $\mathrm{I}_{1}$ & 71.3 & 1.36 & 138.8 & 1.87 & 268.7 & 2.14 & 179 & 1.78 & 657.8 \\
\hline $\mathrm{I}_{2}$ & 71.3 & 1.36 & 128.9 & 1.73 & 255.1 & 2.04 & 147.3 & 1.63 & 602.6 \\
\hline $\mathrm{I}_{3}$ & 71.3 & 1.36 & 113.1 & 1.53 & 225.4 & 1.79 & 131.6 & 1.48 & 541.4 \\
\hline $\mathrm{I}_{4}$ & 71.3 & 1.36 & 104.3 & 1.41 & 185.7 & 1.48 & 112.6 & 1.33 & 473.9 \\
\hline $\mathrm{I}_{5}$ & 71.3 & 1.36 & 133.8 & 1.80 & 259.7 & 2.07 & 163.3 & 1.69 & 628.1 \\
\hline $\mathrm{I}_{6}$ & 70.8 & 1.36 & 117.0 & 1.59 & 234.2 & 1.86 & 135.1 & 1.52 & 557.1 \\
\hline $\mathrm{I}_{7}$ & 71.3 & 1.36 & 107.9 & 1.45 & 205.6 & 1.64 & 119.0 & 1.40 & 503.8 \\
\hline $\mathrm{I}_{8}$ & 71.3 & 1.36 & 105.2 & 1.43 & 193.4 & 1.54 & 117.1 & 1.37 & 487.0 \\
\hline $\begin{array}{l}\text { Reference } \\
\text { evapotrans }\end{array}$ & $\begin{array}{c}52.0 \\
\text { ation }\left(\mathrm{ET}_{0}\right)\end{array}$ & & 75.3 & & 125.8 & & 100.9 & & 354.0 \\
\hline
\end{tabular}

slender and white rice, 1000 grain weight $23.5 \mathrm{~g}$ and average yield-7400 $\mathrm{kg} \mathrm{ha}^{-1}$.

For estimation of Kc values, the crop growth periods was divided into initial stage (1 - 15 DAT), development stage (16-45 DAT), reproductive stage (46-75 DAT) and late stage $(76-100 \mathrm{DAT})$.

$$
\mathrm{K}_{\mathrm{C}}=\mathrm{ET}_{\mathrm{c}} / \mathrm{ET}_{\mathrm{o}}
$$

Where $\mathrm{ET}_{\mathrm{c}}$ is crop evapotranspiration and $\mathrm{ET}_{\mathrm{o}}$ is reference crop evapotranspiration. method.

$\mathrm{ET}_{\mathrm{o}}$ was computed by following pan evaporation

$\mathrm{ET}_{\mathrm{o}}=\mathrm{E}_{\mathrm{pan}} \times \mathrm{K}_{\mathrm{pan}}$

$\mathrm{E}_{\mathrm{pan}}=$ Pan evaporation values from class 'A' open pan evaporimeter $(\mathrm{mm})$.

$\mathrm{K}_{\text {pan }}=$ Pan coefficient ( 0.7$)$ obtained as per weather data of RH (\%) wind speed $\left(\mathrm{km} \mathrm{h}^{-1}\right)$ and wind ward side distance of wet fallow as $200 \mathrm{~m}$ as suggested by Allen et al. (1998).

\section{RESULTS AND DISCUSSION}

\section{Crop evapotranspiration ( $\left.E T_{c}\right)$}

The ETc of rice during initial stage were more or less equal $(71.3 \mathrm{~mm})$ in all the treatments. The average ETc during establishment period accounted only 12.8 per cent only of the seasonal average ETc (Table 2). During developmental stage the ETc varied between $104.3 \mathrm{~mm}$ in $\mathrm{I}_{4}$ treatment to $138.8 \mathrm{~mm}$ in $\mathrm{I}_{1}$ treatment. Thus, the ETc in different AWD treatments were 74.7 to 92.5 per cent of ETc in continuous submergence $\left(\mathrm{I}_{1}\right)$ treatment. During reproductive period ETc in different AWD treatments varied

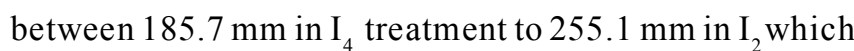
accounted for 69 to 95 per cent of ETc in continuous submergence $\left(\mathrm{I}_{1}\right)$ treatment . During late stage of the crop the ETc varied between 112.6 to $179.0 \mathrm{~mm}$ under different treatment which were low in comparison to that of developmental and reproductive stages in all the treatments due to decrease in LAI and LAD owing to senescence of leaves and probably due to reduced physiological activity. On an average during late stage of the rice ETc in different AWD treatments were 62.6 to 80.2 per cent of ETc in continuous submergence $\left(\mathrm{I}_{1}\right)$ treatment. Thus, the total seasonal ETc was highest in continuous submergence $\left(\mathrm{I}_{1}\right)$ treatment $(657.8 \mathrm{~mm})$ followed by $628.1 \mathrm{~mm}$ in flooding of $5 \mathrm{~cm}$ water when water level drop to $5 \mathrm{~cm} \mathrm{BGL}\left(\mathrm{I}_{5}\right)$ treatment and $602.6 \mathrm{~mm}$ in flooding of $3 \mathrm{~cm}$ water when water level drops to $5 \mathrm{~cm} \mathrm{BGL}\left(\mathrm{I}_{2}\right)$ treatment. The seasonal ETc under AWD irrigation regimes were 69 to 95 per cent of ETc of continuous submergence $\left(\mathrm{I}_{1}\right)$ treatment.

The ETc is a physical process taking place continuously from a periodically replenished source of water and variable potential viz., soil moisture reservoir to a sink of virtually unlimited capacity i.e. the atmosphere. As long as the water availability matches the rate of water loss through transpiration by the crop canopy and evaporation from soil surface the actual evapotranspiration (ETa) continues at potential rates as determined by the evaporative demand of the atmosphere as witnessed in $I_{1}, I_{2}$ and $I_{5}$. 
However, as the crop removes water from the soil, the soil moisture content and soil water potential decreases leading to low soil water conductivity thereby resistance to water movement in the soil increases. This tend to decrease water flow in to the plant system causing marked reduction in ETc as could be observed in AWD irrigation regimes viz., $\mathrm{I}_{3}, \mathrm{I}_{4}, \mathrm{I}_{6}$, $\mathrm{I}_{7}$ and $\mathrm{I}_{8}$.

\section{Crop coefficient (Kc)}

Perusal of the data in Table 2 revealed that during establishment period (Initial stage) Kc values were same (1.36) in all the treatments owing to uniform water input during this period since treatments were imposed from $16^{\text {th }}$ DAT. During different sub-growth periods the Kc values were appreciably influenced by different treatments. Rice crop irrigated with continuous submergence treatment $\left(I_{1}\right)$ had highest Kc values in all the growth stages as compared to AWD irrigation regimes (Table 2). During developmental stage Kc values varied between 1.41 to 1.87 . The highest (1.87) $\mathrm{Kc}$ values was in $\mathrm{I}_{1}$ treatment followed by 1.80 in $\mathrm{I}_{5}$ treatment and the lowest (1.41) Kc values was in $\mathrm{I}_{4}$ treatment followed by 1.43 in $\mathrm{I}_{8}$ treatment. During reproductive stage $\mathrm{Kc}$ values varied between 1.48 in $\mathrm{I}_{4}$ treatment to 2.14 in $\mathrm{I}_{1}$ treatment. While during late stage Kc values varied between 1.33 and 1.78 . The trend of variation was similar in all the three growth stages.

Allen et al. (1998) suggested $\mathrm{Kc}$ values for permanently flooded rice $1.05,1.20$ and 0.9 to 0.6 , during the initial, mid-season, and late-season stages, respectively. Tyagi et al. (2000) reported mean Kc values of 1.15, 1.23, 1.14 and 1.02 for the initial, crop development, reproductive and maturity stages, respectively, for the semiarid conditions of Karnal (India) and total season length of about 150 days. Choudhury et al. (2013) and Sunil Kumar (2017) in the Indo Gangetic Plains (IGP) of India estimated Kc values from field water balance measured ETc and Penman-Monteith estimated reference ETo for dry-seeded irrigated bed planted rice and also compared with conventional dry-seeded flat system of planting. The Kc values of rice during initial, crop development, mid-season and late-season stages on beds were $0.62,0.75,1.16$ and 0.67 , respectively while in conventional flat land, corresponding Kc values were 0.61 , $0.97,1.42$ and 0.91 , respectively. They opined that bed geometry led variation in plant population density influenced strongly both crop ETc losses as well as Kc values. Whereas for aerobic rice and irrigated dry land crop the Kc values were $0.95,1.0$, and 0.97 for the vegetative, reproductive and the ripening stages, respectively (Alberto et al., 2011;
Patil and Manickam, 2017).

To use the $\mathrm{K}_{\mathrm{c}}$ values in Table 2 for predicting $\mathrm{ET}_{\mathrm{c}}$ throughout the crop growing season, only $\mathrm{ET}_{\mathrm{o}}$ estimates based on Penaman Monteith are needed for the new planting site. Models or water production functions which explain yield as a function of $\mathrm{ET}_{\mathrm{c}}$ will be of limited use until

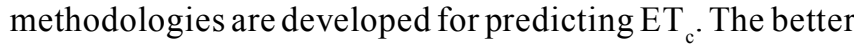
known approach is the prediction of $\mathrm{ET}_{\mathrm{c}}$ i.e., the $\mathrm{ET}_{\mathrm{c}}$ requirement of the crop not just as a simple value for the season, but as a cumulative value over time which shows the differential $\mathrm{ET}_{\mathrm{c}}$ needs in each individual crop growth sub$\operatorname{period}\left(\mathrm{ET}_{\mathrm{c}}=\mathrm{K}_{\mathrm{c}} . \mathrm{ET}_{\mathrm{o}}\right)($ Mehta and Pandey, 2015).

\section{CONCLUSION}

The different treatments of alternate wetting and drying (AWD) saved 13.7 to 36.4 per cent of water in comparison to continuous submergence treatment. The crop evapotranspiration (ETc) and Kc values were highest under continuous submergence condition treatment in all the growth stages of the crop and lowest in treatment having flooding of $3 \mathrm{~cm}$ water when water levels drops to $15 \mathrm{~cm}$ below ground level. Crop coefficients, derived will facilitate prediction of ETc and irrigation requirement of ETc rice crop in advance for planning irrigation strategies.

\section{REFERENCES}

Alberto, M.C.R., Wassmann, R., Hirano, T., Miyata,A., Hatano, R., Kumar, A., Padre, A. and Amante A. (2011). Comparisons of energybalance and evapotranspiration between flooded and aerobic rice fields in the Philippines. Agric. Water Manage.,98: 1417 - 1430.

Allen, R.G., Pareira, LS., Raes, D. and Smith, M. (1998). Crop evapotranspiration guidelines for computing crop water requirements. Rome: FAO-Food and Agriculture Organization of the United Nations.

Bhavsar, P.N and Patel, J. N. (2016). Development of relationship between crop coefficient and NDVI using geospatial technology. J. Agrometeorol., 18 (2): 261-264.

Bouman, B.A.M., Humphrey, E., Tuong, T.P and Barker, R. (2007). Rice and water. Adv. Agron.,92(4): 187-237.

Choudhury, B.U., Singh,A.K and Pradhan, S. (2013). Estimation of crop coefficients of dry-seeded irrigated rice-wheat rotation on raised beds by field water balance method in the Indo-Gangetic plains, India. Agric. Water Manage.,123: 20 - 31 . 
Department of Agriculture, Telangana. (2014).

Mehta, R. and Pandey, V. (2015). Reference evapotranspiration and Crop water requirement (ETc) of wheat and maize crop in Gujarat. J. Agrometeorol., 17 (1): 107-113.

Patil C. S and Manickam, R. (2017). Crop evapotranspiration and crop coefficient of soybean (Glycine max L. Merrill) in Bengaluru, Karnataka. J. Agrometeorol., 19 (3): 292293.

Rosegrant, M.W., and Ringler, C. (1998). Impact on food security and rural development of transferring water out of agriculture. Water Policy., 1(6): 567-586.

Sunil, K. (2017). Reference evapotranspiration and irrigation water requirement of different crops in Bihar. J.Agrometeorol., 19 (3): 238-241.
Tabbal, D.F., Bouman, B.A.M., Bhuiyan, S.I., Sibayan, E.B and Sattar, M.A. (2002). On-farm strategies for reducing water input in irrigated rice. Agric. Water Manage., 56(2): 93-112.

Tuong T.P. (2007). Alternate Wetting and Drying Irrigation (AWD): a technology for water saving in rice production. Paper presented at the Crop Cutting Ceremony, BADC Farm, Modhupur, Tangail.

Tyagi, N.K., Sharma, D.Kand Luthra, S.K.(2000). Determination of evapotranspiration and crop coefficients of rice and sunflower with lysimeter. Agric. Water Manage., 45: 4154. 